\title{
The Arctic's rapidly shrinking sea ice cover: a research synthesis
}

\author{
Julienne C. Stroeve • Mark C. Serreze • \\ Marika M. Holland • Jennifer E. Kay • \\ James Malanik • Andrew P. Barrett
}

Received: 15 February 2011 / Accepted: 22 April 2011 / Published online: 8 June 2011

(C) The Author(s) 2011. This article is published with open access at Springerlink.com

\begin{abstract}
The sequence of extreme September sea ice extent minima over the past decade suggests acceleration in the response of the Arctic sea ice cover to external forcing, hastening the ongoing transition towards a seasonally open Arctic Ocean. This reflects several mutually supporting processes. Because of the extensive open water in recent Septembers, ice cover in the following spring is increasingly dominated by thin, first-year ice (ice formed during the previous autumn and winter) that is vulnerable to melting out in summer. Thinner ice in spring in turn fosters a stronger summer ice-albedo feedback through earlier formation of open water areas. A thin ice cover is also more vulnerable to strong summer retreat under anomalous atmospheric forcing. Finally, general warming of the Arctic has reduced the likelihood of cold years that could bring about temporary recovery of the ice cover. Events leading to the September ice extent minima of recent years exemplify these processes.
\end{abstract}

\section{Introduction}

Arctic sea ice extent over the modern satellite record (1979-present) shows downward trends in all months, smallest in winter and largest at the end of the summer

\footnotetext{
J. C. Stroeve $(\varangle) \cdot$ M. C. Serreze · A. P. Barrett

National Snow and Ice Data Center, Cooperative Institute for Research in Environmental Sciences, University of Colorado, Boulder, Boulder CO, USA

e-mail: stroeve@kryos.colorado.edu

M. M. Holland · J. E. Kay

National Center for Atmospheric Research, Boulder CO, USA

J. E. Kay

Department Atmospheric Sciences, Colorado State University, Fort Collins, CO, USA

J. Malanik

Colorado Center for Astrodynamics Research, University of Colorado,

Boulder, Boulder CO, USA
} 
melt season in September (Serreze et al. 2007a). The period from 2002 onwards has seen a series of extreme September extent minima. A new record minimum was set in 2005, followed by some recovery in 2006. Then, in September 2007, Arctic sea ice extent fell to the lowest value ever recorded, $23 \%$ below the 2005 minimum (Stroeve et al. 2008). Including the last three Septembers (2008-2010), which ended up with the second, fourth and third lowest extents in the satellite record, respectively, the September linear trend stands at $-12.4 \%$ per decade (Fig. 1).

The downward trend in September ice extent is best explained from a combination of natural variability in air temperature, atmospheric and ocean circulation, and forcing from rising concentrations of atmospheric greenhouse gases (GHGs; e.g. Serreze et al. 2007a, b). Hindcast simulations from all coupled global climate models used in the Intergovernmental Panel on Climate Change (IPCC) Fourth Assessment Report (AR4) that incorporate observed climate forcings show declining September

Fig. 1 Color map (left): monthly sea ice concentration for September 2010. The red line marks the September 2007 extent, the orange line is the extent for September 2008, the green line the September 2009 extent and the pink line is the climatological (1979-2000) monthly mean for September. Right Time-series of monthly averaged September sea ice extent with linear trend line

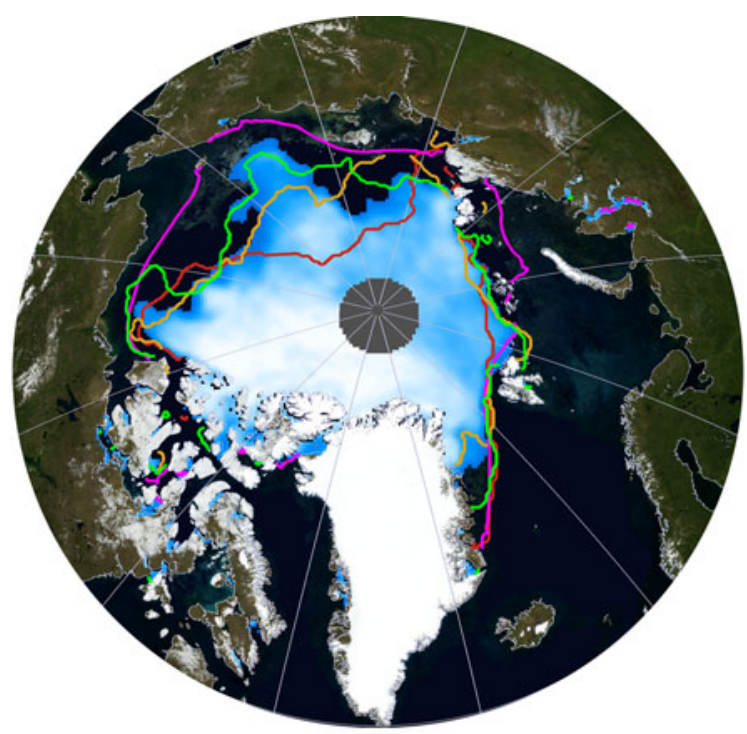

Average Monthly Arctic Sea Ice Extent September 1979 to 2010

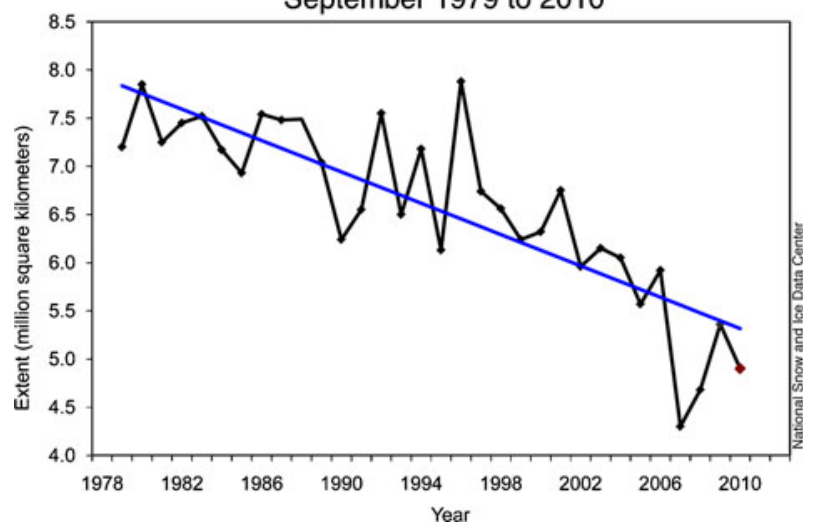


ice extent over the period of observations (Stroeve et al. 2007; Zhang and Walsh 2006). Although this is strong evidence for a role of GHG forcing on the observed trend, the simulated trends, as a group, are smaller than observed. This has raised speculation that ice-free summers might be realized as early as 2030 (Stroeve et al. 2007).

Some of the IPCC simulations show that the decline in September ice extent becomes steeper with time, but only later into the twenty-first century (e.g. Wang and Overland 2009). Are we starting to see an accelerating decline in ice extent, hastening the transition to a seasonally ice-free Arctic Ocean? We argue that while the statistical evidence for accelerating ice loss is only beginning to emerge, there is ample physical evidence of growing non-linear response to external climate forcing (Fig. 2). First, because of the extensive open water in recent Septembers, ice cover in the following spring is increasingly dominated by thin, first-year ice (ice formed during the previous autumn and winter) that is vulnerable to melting out in summer, especially under the influence of anomalous atmospheric circulation patterns that favor summer melt (Lindsay et al. 2009). Second, the existence of more thin ice in spring, implying a more fragmented ice cover, allows open water areas to develop earlier in the melt season, leading to increased importance of the ice-albedo feedback (Perovich et al. 2007). Third, the Arctic has warmed in all seasons (Serreze et al. 2009), leading not only to earlier melt onset (Markus et al. 2009), but also a reduced likelihood of unusually cold conditions that could bring about temporary recovery through natural climate variability.

We synthesize evidence for these linked processes through analysis of satellitederived sea ice extent, ice concentration and ice age, and atmospheric conditions from atmospheric reanalyses and satellite observations. We first discuss evidence for steepening of the trend in September ice extent. Attention then turns to the changes in the spring ice age distribution (a proxy for ice thickness), the relationship between

Fig. 2 Illustration of mutually supporting processes favoring acceleration of the September sea ice trend

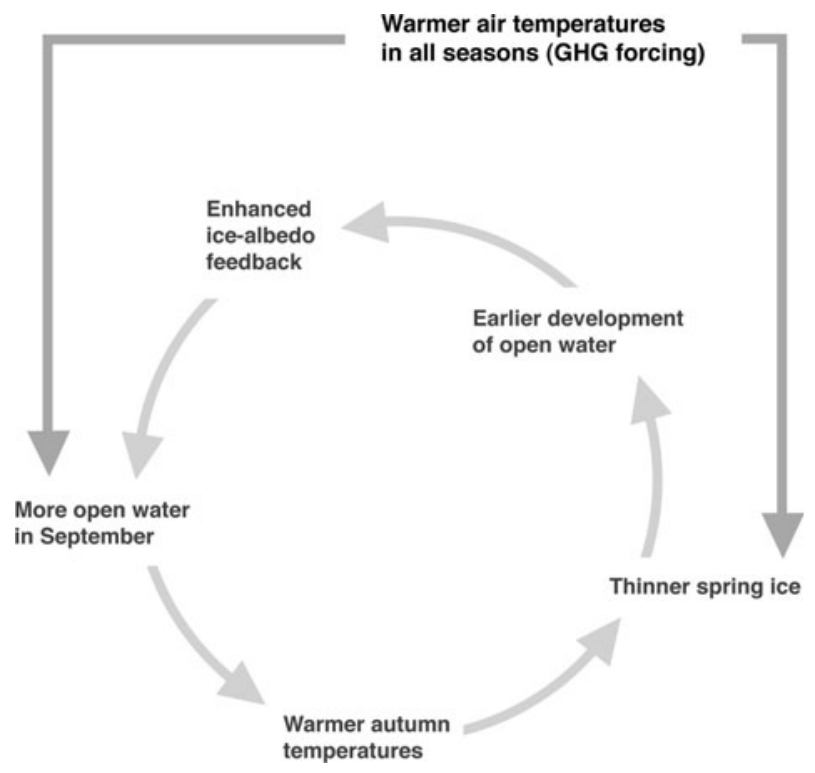


September ice extent and March first-year ice coverage, how thinner spring ice leads to a stronger influence of the ice-albedo feedback, and the characteristics of recent Arctic warming. Significance of the transition towards a thinner spring ice cover is then illustrated by comparing and contrasting sea ice and atmospheric conditions during the 2007, 2008, 2009 and 2010 melt seasons. We conclude by discussing implications of the linked processes for the evolution and predictability of the sea ice conditions in coming decades.

\section{Sea ice and atmospheric data}

The National Snow and Ice Data Center (NSIDC) provides daily and monthly fields of sea ice concentration at $25 \mathrm{~km}$ spatial resolution derived from Scanning Multichannel Microwave Radiometer (SMMR) and Special Sensor Microwave/Imager (SSM/I) brightness temperatures using the NASA Team sea ice algorithm (Cavalieri et al. 1996; Meier et al. 2006). The combined record extends from October 1978 through present.

Ice age is derived from an algorithm developed by Fowler et al. (2004), applied to ice motion fields derived from a combination of satellite passive microwave, visible and thermal imagery and drifting ocean buoys. Ice motion is calculated from a cross correlation technique applied to sequential daily satellite images. These satellite-derived motion fields are then blended with buoy drift vectors via optimal interpolation to create the final motion product. Ice age is estimated by treating each grid cell that contains ice as an independent Lagrangian particle and advecting the particles at weekly time steps and using an ice concentration threshold of $15 \%$. At the end of each melt season, remaining ice is aged one1 year. No area weighting is used. Rather, a pixel is assigned the age of the oldest "particle" that lies in the domain of that pixel. Fowler et al. (2004), Rigor and Wallace (2004) and Maslanik et al. (2007) provide further details. We limit the ice age analysis to the Arctic Ocean domain. This is the same domain used in the heat budget analysis of Serreze et al. (2007b).

Fields of near surface air temperature, sea level pressure and absorbed solar radiation at the surface are obtained from the JRA-25 atmospheric reanalysis, a product of the Japan Meteorological Agency (Onogi et al. 2007). Data from the NASA A-Train constellation of satellites, including radar and lidar data (e.g. CloudSat) that do not rely on thermal or albedo contrasts to detect clouds (Stephens et al. 2008) are used to contrast Arctic cloud conditions for recent years.

\section{Accelerating decline in September ice extent?}

Comiso et al. (2008) argue for a steepening trend in September sea ice extent on the basis of a statistically-significant difference in linear regression slopes computed for an earlier (1979-1996) and a later (1996-2007) time-period. Following this approach, the top panel of Fig. 3 shows regression slopes for the periods 1979-1998 (blue line) and 1999-2010 (red line). The slopes are computed for the Arctic Ocean domain as defined in the study of Serreze et al. (2007b). Comiso et al. (2008) by comparison considered the Northern Hemisphere sea ice cover as a whole, which includes ice in the East Greenland Sea and the Canadian Archipelago. The slopes 
are $-0.032+0.017$ million $\mathrm{km}^{2}$ year ${ }^{-1}$ and $-0.154 \pm 0.038$ million $\mathrm{km}^{2}$ year $^{-1}$, respectively, and are statistically different from each other at a $95 \%$ confidence level. A smoothed curved trend line computed using Locally Weighted Scatterplot Smoothing (LoWeSS; Cleveland and Devlin 1988) for the entire period of record is also shown (green) and further supports the argument for a recent increase in the rate of ice loss.

One aspect of the data that complicates significance testing of the difference in slopes using linear-least squares is that the data exhibit increased variability after 1990 (Fig. 3, bottom panel). For the Arctic Ocean domain over the period 1979 to 1990, the standard deviation is 0.34 million $\mathrm{km}^{2}$; while from 1990 to 2010 it is 0.51 million $\mathrm{km}^{2}$. This increase in variability coincides with an early 1990s shift in the spring ice thickness distribution in the Arctic Ocean domain towards a larger fraction of thin, first-year ice (e.g. Maslanik et al. 2007; Nghiem et al. 2007), linked in turn to a period when the Arctic Oscillation (AO), also referred to as the Northern Annular Mode (NAM), was generally in a strongly positive phase (Rigor and Wallace 2004; discussed in more detail below). An increase in variability of summer ice extent as the spring ice cover thins is a feature of coupled global climate model simulations (e.g.

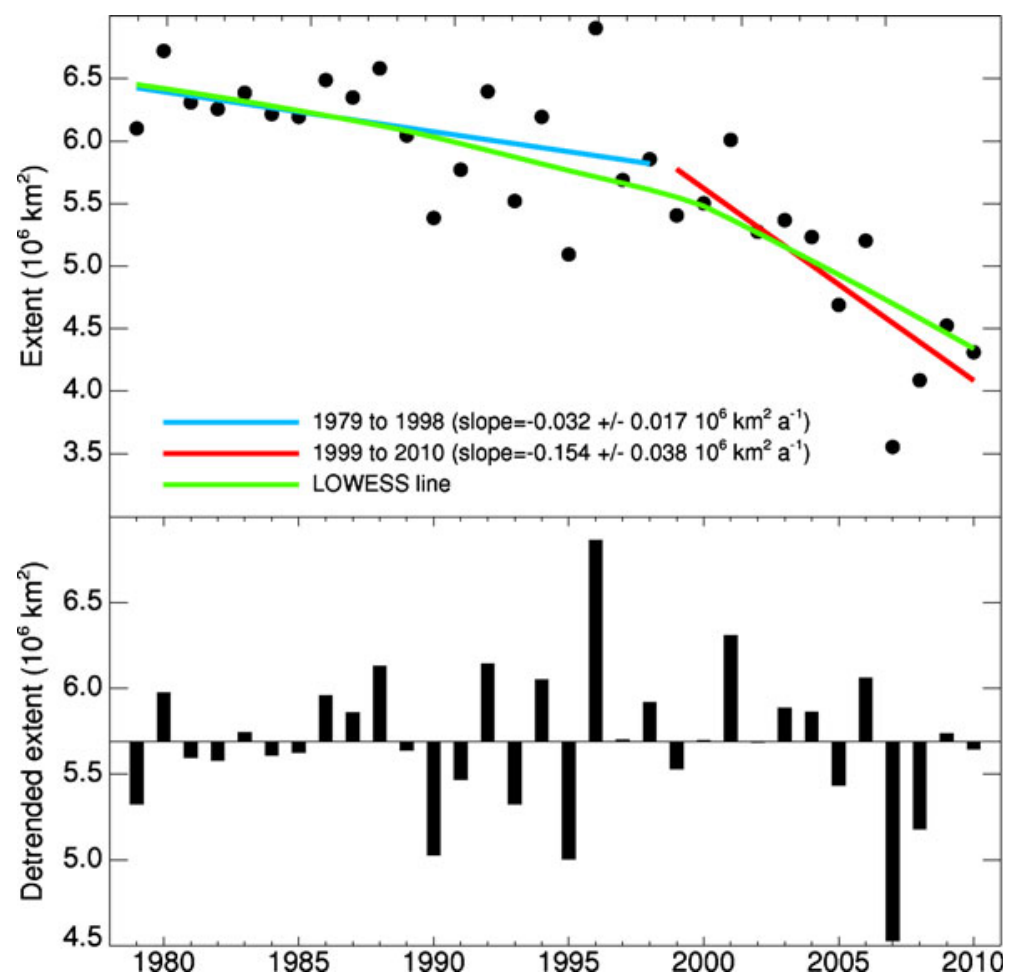

Fig. 3 September sea ice extent with smoothed non-linear trend line (green), and linear trend lines for 1979 to 1998 (blue) and 1999 to 2010 (red) [top] and detrended sea ice extent calculated by subtracting non-linear trend (green line in top panel) from observed September extent [bottom]. The smoothed non-linear trend line is calculated using Locally Weighted Scatterplot Smoothing (LoWeSS). Linear trends are calculated using least-squares regression 
Holland et al. 2008). The reasoning is that as the ice cover thins, large regions become especially vulnerable to melting out during summer under favorable atmospheric conditions. Conversely, even in a warming climate, occasional summers are cool enough for much of the first-year ice to survive. The overall result is increased variability.

Models also project an accelerating rate of decline of September sea ice extent (e.g. Wang and Overland 2009) with many showing this feature by the time that September ice extent has reached the values seen today. Yet even during decadal or multi-decadal periods of generally rapid ice loss such as those evident in the NCAR Community Climate System Model Version 3 (CCSM3) simulations (Holland et al. 2006), there are periods of slow ice loss or even temporary increases in extent. Thus, while the observed trend is steeper over the past decade compared to the earlier part of the record, it is uncertain if this pattern will be sustained. The higher extent for September 2009 relative to the previous 2 years (Fig. 1) may have suggested a temporary recovery, yet September 2010 saw less ice compared to 2009 despite a winter circulation pattern that should have helped to favor ice retention through the summer melt season (Stroeve et al. 2011).

\section{Linked processes}

\subsection{More first-year ice in spring}

As just mentioned, the Fowler et al. (2004) ice age calculations indicate a temporal shift in the distribution of ice age classes in spring towards less multiyear ice and more first-year ice (Fig. 4). In the early and mid 1980s, 38\% of the ice cover in spring consisted of first-year ice (2.96 million $\mathrm{km}^{2}$ of the Arctic Ocean domain) with the remainder being older ice that had survived one or more melt seasons. Nearly $30 \%$ of that older ice $\left(2.33\right.$ million $\mathrm{km}^{2}$ ) was 5 years or older. Since older ice is generally thicker than first-year ice (e.g. Maslanik et al. 2007), these large areas of thick ice will help to stabilize the summer ice cover, for while an unusually warm summer may promote a strong negative anomaly in September ice volume, it can only promote a fairly modest negative anomaly in September ice extent.

As previously documented by Maslanik et al. (2007), the first-year ice fraction increased to $52 \%$ (4.02 million $\mathrm{km}^{2}$ ) by spring 1996 and the fraction of ice more than 5 years old had declined to $18 \%\left(1.40\right.$ million $\left.\mathrm{km}^{2}\right)$. As outlined above, this decline is linked to behavior of the winter AO, which turned strongly positive in the late 1980s and early 1990s. This change in the AO was reflected in a counter-clockwise (cyclonic) anomaly in the sea ice circulation pattern helping to both transport thick ice out of the Arctic Ocean via Fram Strait and promote first-year ice production in areas of ice divergence along the Eurasian coastal seas (Rigor and Wallace 2004). However, since about the year 1995, the AO has alternated between positive and negative states, and yet the first-year ice fraction in spring has continued to increase. In spring 2007, 55\% (4.03 million $\mathrm{km}^{2}$ ) of the Arctic Ocean domain consisted of first-year ice, and this fraction increased to $72 \%$ (5.39 million $\mathrm{km}^{2}$ ) in spring 2008 , following the dramatic September sea ice minimum of 2007. The lack of substantial recovery in 2008 resulted in a continuation of anomalously high fraction of first-year-ice $\left(67 \%\right.$ or 5.03 million $\mathrm{km}^{2}$ ) in spring 2009 . While summer 2009 saw a 
Fig. 4 Distribution of ice age classes 1 through $5+$ during March (top) and at end of the melt season (middle). The ice survival rates for first-year, second year and ice 3 years or older is shown at bottom
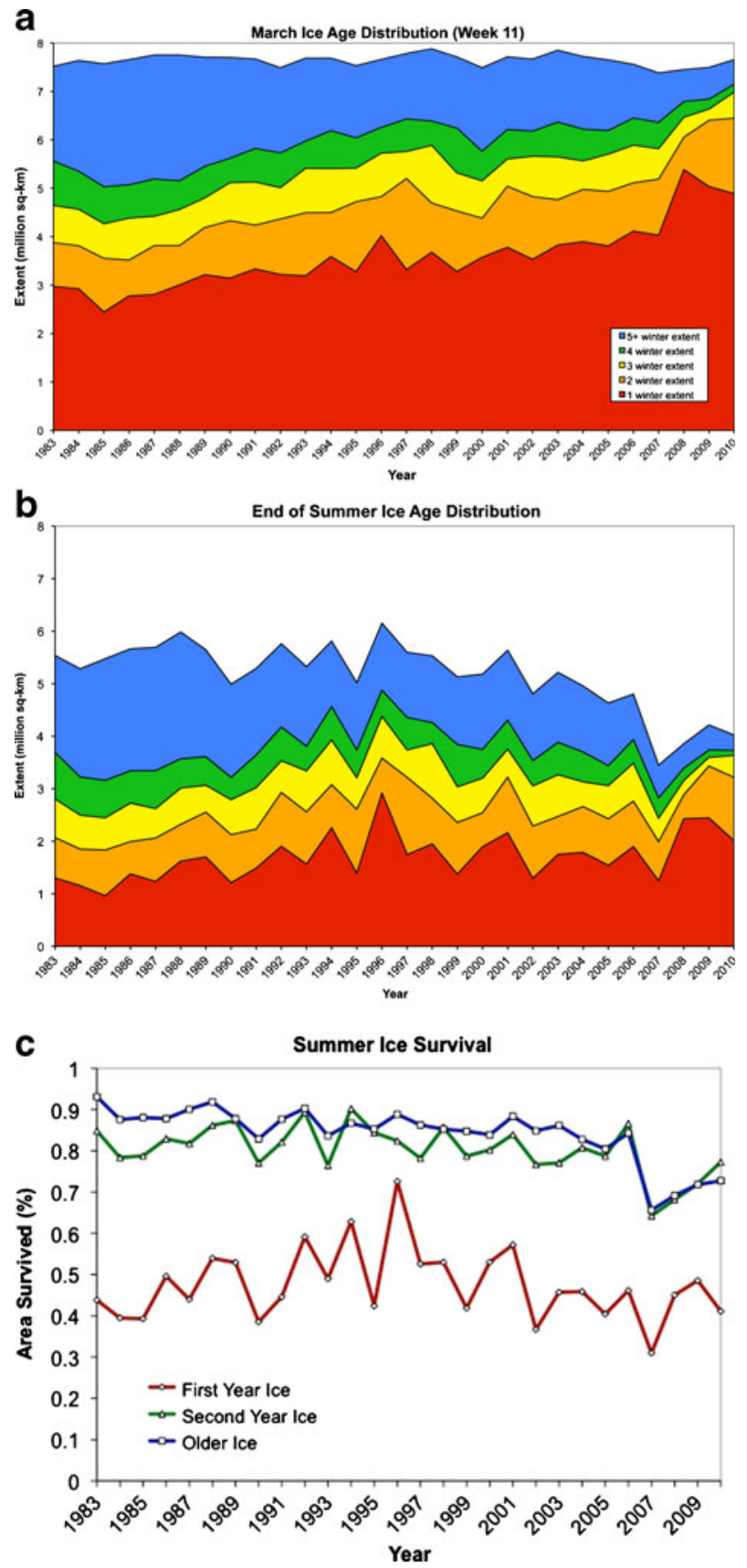

further recovery, $64 \%$ of the 2010 spring ice cover remained first-year ice. Perhaps more important is that spring 2010 saw a record low in the amount of ice 5 years or older (less than $700,000 \mathrm{~km}^{2}$ ). 
First-year ice extent in a given March represents ice that grew during the previous autumn and winter. Hence, in a simple thermodynamic system, September open water extent should have value as a predictor of the following March first-year ice extent. That the linear correlation between de-trended September ice extent and the following March first-year extent over the period 1980-2010 is of the expected sign but a fairly modest -0.70 manifests limits on predictability caused by variability in ice dynamics. Not surprisingly, the correlation is sensitive to the time period examined. For example, assessed over the period 1980-2000 the correlation between the detrended time series is only -0.53 , and not statistically significant. This can likely be attributed to the shift towards the strong positive phase of the winter AO (Rigor and Wallace 2004). The much stronger correlation over the more recent period, 20012010 of -0.93 , points to a smaller influence of the AO in dynamically shaping the characteristics of the March ice cover. As outlined in the introduction, simulations with coupled climate models suggest that at least part of the observed negative trend in September ice extent (a positive trend in open water area) is externally forced. It hence follows that external forcing has contributed in part to the observed increase in first-year ice coverage in spring, but that natural variability is also a key player (Maslanik et al. 2007).

\subsection{Growing importance of the ice albedo feedback}

The ice-albedo feedback has always been part of the sea ice system. As the melt season commences, bare ice is exposed by melting snow. Melt ponds form and areas of dark open water (low albedo) are exposed, which readily absorb solar radiation, fostering further ice melt. Without this feedback, the amplitude of the seasonal cycle in ice extent (the change from March through September) would be smaller than is observed. The downward trend in September ice extent has in part been attributed to a growing importance of the ice-albedo feedback (Perovich et al. 2007; Lindsay and Zhang 2005). This is because the transition to an Arctic ice pack dominated by thin, first-year ice in spring likely results in a more fractured ice pack, with more pancake ice, more leads, and less structural integrity. Thus, open water areas are exposed earlier in the melt season and become more extensive throughout summer, further accentuating summer ice melt. As an illustration of the process, Fig. 5 shows weekly trends in ice concentration for different regions of the Arctic Ocean (see Fig. 10 inset for region definitions). Negative trends, towards lower concentration, dominate all regions by week 17 (3rd week of April), reflecting a combination of less sea ice (i.e. more open water) and/or more surface melt (i.e. melt ponds that result in lower ice concentration values as retrieved from passive microwave data, see Steffen et al. 1992). These negative trends in ice concentration imply a corresponding decrease in surface albedo since open water has a much lower albedo than sea ice (typically 0.07 versus 0.65 for bare ice and up to 0.85 for snow-covered sea ice). Note that the growing ice-albedo feedback as discussed here is directly related to the coverage of more thin, first-year ice that allows for a longer duration of exposed open water areas as represented in Fig. 5 (and an overall reduction in the Arctic Basin albedo), and it is not a function of change in the correlation and/or sensitivity between melt and ice albedo.

To further illustrate the growing feedback, monthly-mean incoming solar radiation and surface albedo were extracted from the JRA-25 archives for the months 


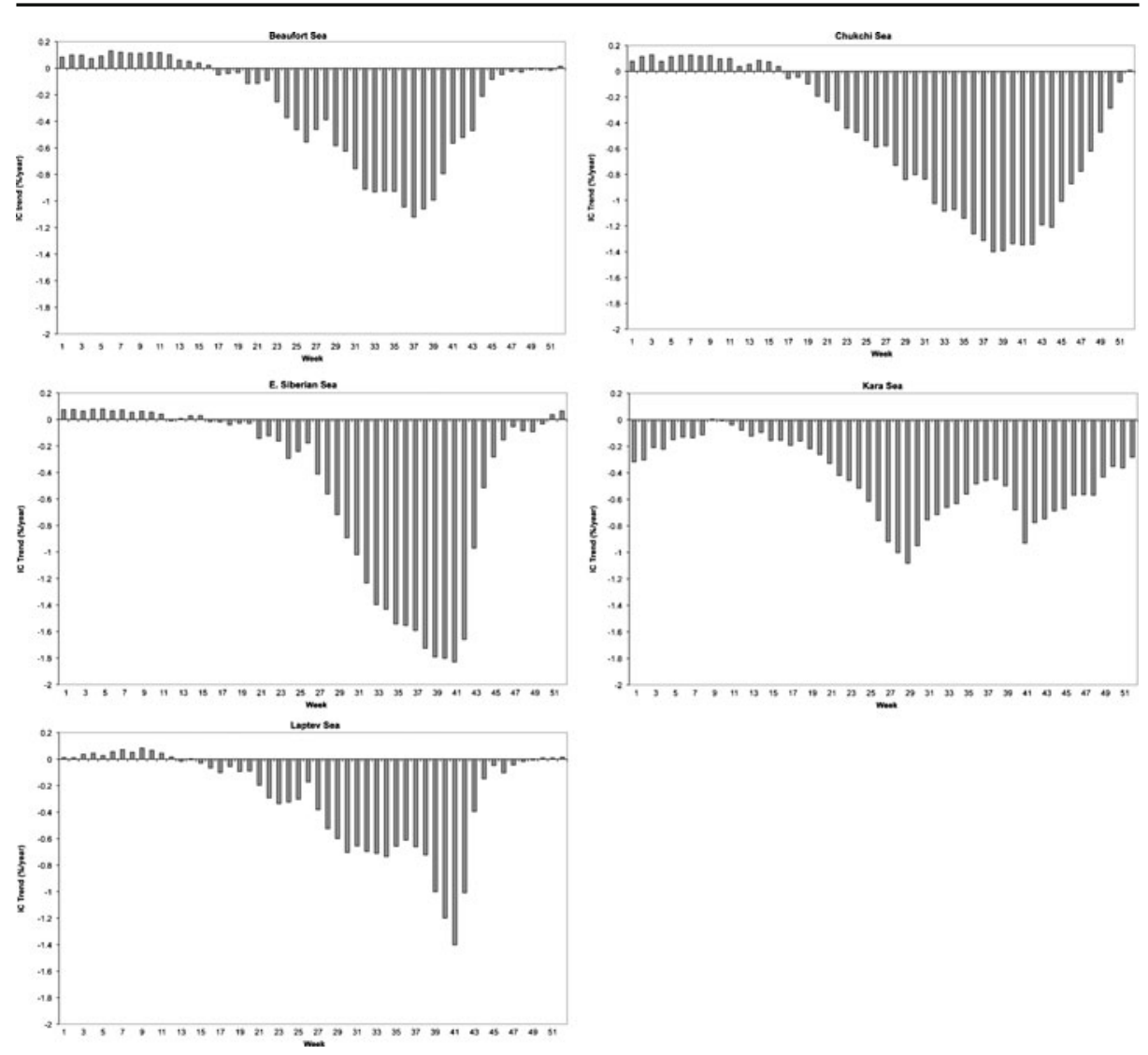

Fig. 5 Weekly trends in sea ice concentration (\%/year) for the Beaufort, Chukchi, East Siberian, Laptev and Kara seas. Trends are computed for the period 1979 to 2010. See Fig. 10 inset for definition of regions

April through September of each year, 1979-2010 (JRA-25 starts in 1979, the beginning of the modern satellite era) from which the total absorbed solar radiation at the surface was calculated. Although there are large known biases in Arctic radiative fluxes and cloud radiative forcing in reanalyses products (e.g. Walsh et al. 2009), JRA-25 reanalysis fields were used since there currently is no up-to-date, long-term satellite data product of surface albedo or absorbed solar radiation for the Arctic region.

Fields of monthly mean absorbed solar radiation averaged for the last 6 years of the available record (2005-2010, corresponding to the advent of the most recent extreme September sea ice minima, see Fig. 1) were then expressed as anomalies with respect to a 1979-2010 climatology. Figure 6 shows cumulative anomalies for May through August for 2005-2010 in units of $\mathrm{MJ} \mathrm{m}^{-2}$ (i.e. the panel for May is the anomaly for that month, that for June is the anomaly for May plus June, that for July is the anomaly for May plus June plus July, etc.). The JRA-25 data are provided on a 1.25 degree latitude/longitude grid. To improve clarity, results were interpolated to a $100 \mathrm{~km}$ equal-area grid. JRA-25 uses ice concentration fields from SMMR and $\mathrm{SSM} / \mathrm{I}$ as surface boundary conditions. 

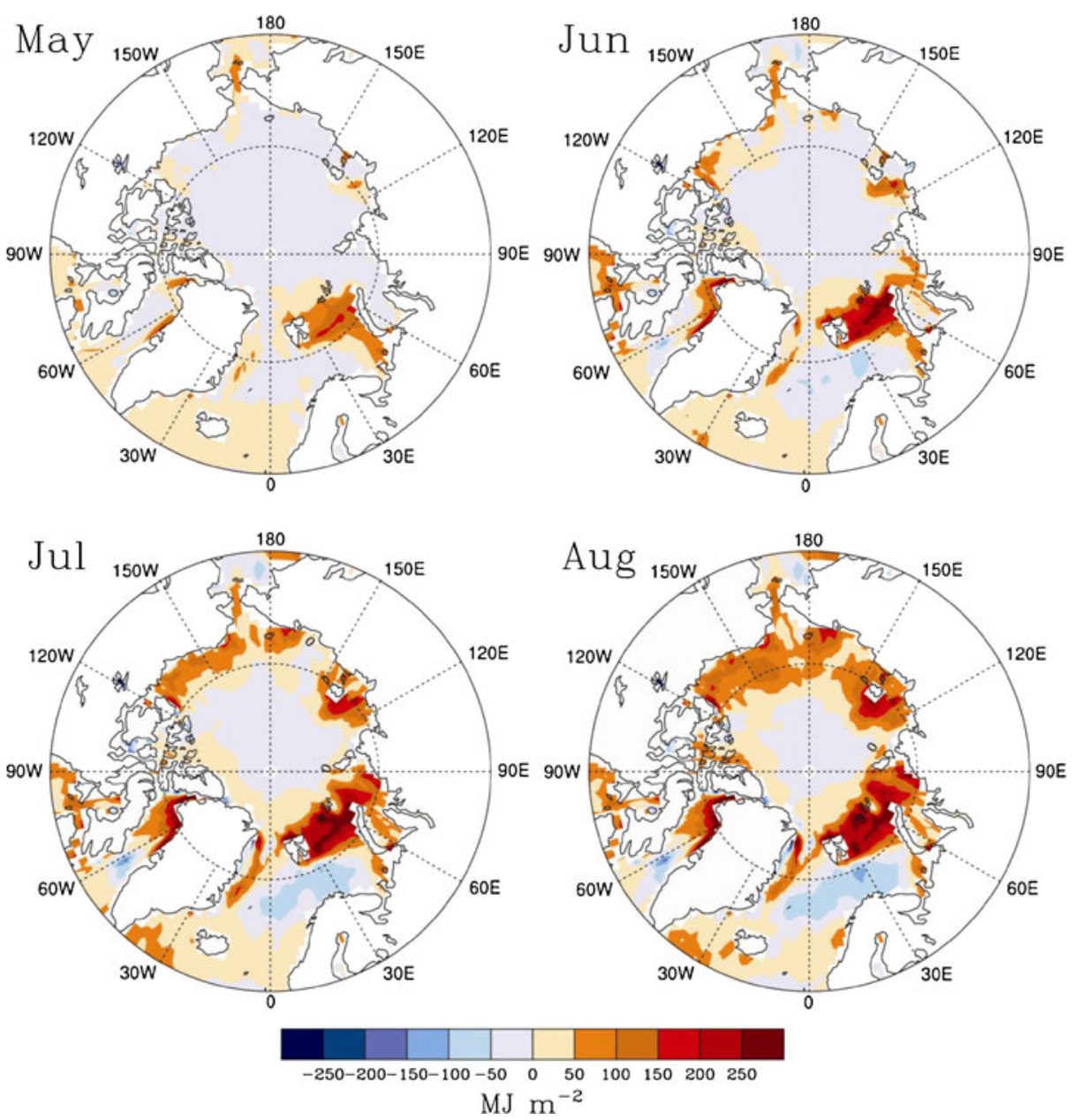

Fig. 6 Cumulative anomalies in absorbed solar radiation for May, June, July and August for the 7-year period 2005-2010, based on monthly fields from the JRA-25 reanalysis interpolated to a 100$\mathrm{km}$ equal-area grid array. Anomalies $\left(\mathrm{MJ} \mathrm{m}^{-2}\right)$ are with respect to 1979-2010 means (see text for details)

The panel for May is characterized by large positive anomalies in absorbed solar radiation in the Barents Sea, and smaller positive anomalies along the east coast of Greenland, Baffin Bay and Bering Strait that correspond to lower than average spring ice extent and concentration for the 6-year period. Positive anomalies in absorbed solar radiation grow in magnitude and spatial extent through the melt season, strongly expressed in the Beaufort, Chukchi, E. Siberian, Laptev, Kara and Barents seas by August. Cumulative anomalies for August locally exceed $150 \mathrm{MJ} \mathrm{m} \mathrm{m}^{-2}$, representing an equivalent melt of ice thickness of $49 \mathrm{~cm}$ assuming an ice density of $917 \mathrm{~kg} \mathrm{~m}^{-3}$ and latent heat of fusion of $334000 \mathrm{~J} \mathrm{~kg}^{-1}$. Results for the record September sea ice minimum of 2007 (not shown) document an especially prominent feedback. Perovich et al. (2008) used similar techniques to estimate anomalies in absorbed shortwave radiation over the Beaufort and Chukchi accumulated through 
the 2007 melt season (using operational fields from the European Centre for Medium Range Weather Forecasts). Compared to averages for 1979-2005, anomalies of 500\% in solar heat input to the upper ocean characterized much of the region in 2007.

Increased absorption of solar radiation in open waters in summer will impact on the survivability of the summer sea ice (Fig. 4). On average about $40 \%$ of first-year ice survives the melt season and about $80 \%$ of the older ice types survive. However, in 2007 and 2008, less of the older ice survived summer, and 2007 had a record low survivability of first-year ice $(16 \%)$. In addition, heat consequently gained by the Arctic Ocean mixed layer must be released back to the atmosphere before sea ice can once again form in the autumn and winter, leading to a shorter ice growth season as well as higher autumn air temperatures (see below).

The results in Fig. 6 also manifest influences of cloud cover. Negative anomalies in absorbed solar radiation over much of the Atlantic in July and August reflect in part negative anomalies in cloud extent or optical thickness.

\subsection{A warming climate}

Air temperatures averaged across the Arctic Ocean domain are rising (e.g. ACIA 2004 and references therein). Figure 7 shows temperature anomalies at the $925 \mathrm{hPa}$ level for the Arctic Ocean domain from JRA-25 by year and month (top) and

Fig. 7 JRA-25 $925 \mathrm{hPa}$ temperature anomalies by year and month (top) and averaged for extended summer (MJJAS, middle) and extended winter (ONDJFMA, bottom) seasons. Results are for an Arctic Ocean domain. Anomalies are computed with respect to the period 1979-2010
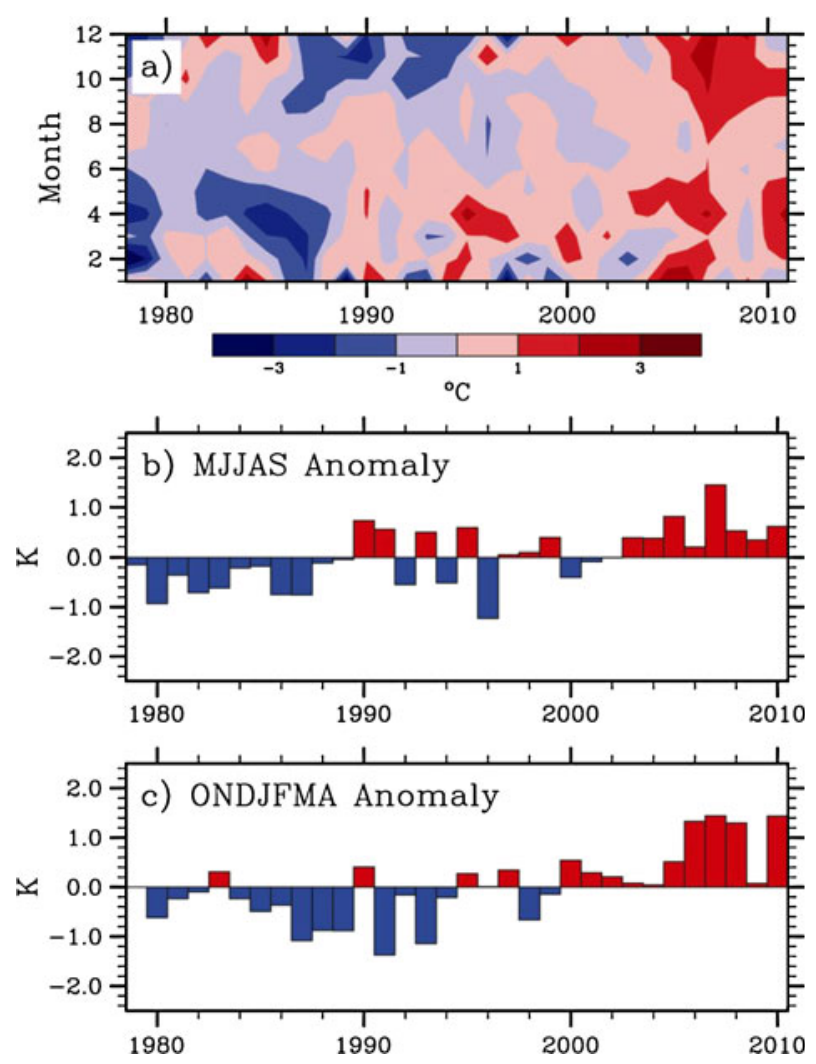
averaged for extended summer (MJJAS, middle) and extended winter (ONDJFMA, bottom) seasons. Anomalies are computed with respect to means for the period 1979-2010.

In the earlier part of the record, it was common for an anomalously warm summer, contributing to a negative anomaly in September ice extent, to be followed by an anomalously cold winter or cold summer, helping to bring about recovery of the ice cover. Since about 2000, positive anomalies dominate all months. This warmer Arctic climate has been linked to increased concentrations of atmospheric greenhouse gases, increased concentrations of black carbon aerosols (Shindell and Faluvegi 2009), increased spring cloud cover that has increased downward longwave radiation at the surface (Francis and Hunter 2006), variability in atmospheric circulation and horizontal atmospheric energy transport convergence (Yang et al. 2010), and reductions in ice extent (discussed shortly). Particularly through impacts on ice extent, altered ocean heat transport may also play a role (Polyakov et al. 2005; Shimada et al. 2006).

Warmer temperatures in spring have contributed to earlier melt onset throughout the Arctic (e.g. Markus et al. 2009; Belchansky et al. 2004), leading to earlier reductions in albedo and increased absorption of solar radiation that further melt the ice. Deposition of black carbon and other impurities on snow covered and bare sea ice may further increase absorption of solar radiation. Positive air temperature anomalies are especially strong for recent years during October, a month after the seasonal sea ice minimum. Rigor et al. (2002) discussed the existence of a lag correlation between the prior winter AO index and air temperature during autumn, such that less summer sea ice after a positive AO winter resulted in warmer autumn atmospheric temperatures from the release of ocean heat during autumn freeze-up. More recent studies have shown that the recent autumn warming signal is linked to anomalous open water areas in September, leading to a strong transfer of heat from the ocean mixed layer to the atmosphere, cooling the former and warming the latter (e.g. Serreze et al. 2009; Screen and Simmonds 2010). Atmospheric circulation then spreads the positive atmospheric temperature anomalies horizontally to influence adjacent areas of the Arctic Ocean (Serreze et al. 2009). While ice cannot form over open water areas until the mixed layer loses its heat (for an analysis of observed trends towards later autumn freeze-up, see Markus et al. 2009), the autumn warming over adjacent ice covered areas may also impact ice growth, contributing to a thinner spring ice cover. The major point is that with rising air temperatures in all seasons, prospects for the ice to substantially recover have dimmed.

\section{Evidence from the years 2007 through 2010}

The dramatic September ice extent minimum of 2007 occurred after years of shrinking and thinning of the ice cover linked to natural variability and external forcing, making the ice cover increasingly vulnerable to an anomalous atmospheric event (Lindsay et al. 2009; Stroeve et al. 2008; Maslanik et al. 2007). As pointed out in a number of studies (Kay et al. 2008; L'Heureux et al. 2008; Stroeve et al. 2008; Perovich et al. 2008; Schweiger et al. 2008; Ogi et al. 2008), a key driver of the record 2007 September minimum was an atmospheric pattern, setting up in early July and persisting through summer, featuring unusually high sea level pressure over 
the Beaufort Sea and Canada Basin and unusually low pressure over eastern Siberia. This pattern, recently termed the summer Arctic Dipole Anomaly (DA; Wu et al. 2006; Overland et al. 2008; Wang et al. 2009) leads to warm southerly winds in the Chukchi and East Siberian seas, favoring melt and transporting ice towards the pole. In 2007, the DA was particularly well developed throughout the entire summer, resulting in strong southerly winds that led to anomalously warm air temperatures and transport of ice away from the coasts of Siberia and Alaska towards the North Pole. It also enhanced the transport of ice out of the Arctic Ocean and into the North Atlantic through Fram Strait (Wang et al. 2009), and according to Kay et al. (2008), promoted unusually clear skies in the vicinity of the high-pressure anomaly that enhanced surface and basal melt.

L'Heureux et al. (2008) interpreted the strength and persistence of the strong Beaufort Sea high of summer 2007 as a regional expression of an unprecedented (in the available record) strong positive phase of the Pacific North American (PNA) teleconnection pattern. However, the strength of the Beaufort Sea high was not unprecedented. For example, a stronger positive SLP anomaly in the Beaufort Sea occurred during the summer of 1987 (Kay et al. 2008, Fig. 2). Kay et al. (2008) also show more limited summer cloud cover than 2007 at Barrow for five other years since 1948. Regardless of how one views the summer 2007 atmospheric pattern, it is widely agreed (e.g. Kay et al. 2008; Stroeve et al. 2008; Lindsay et al. 2009; Maslanik et al. 2007; Wang et al. 2009) that without the extensive coverage of thin, first-year ice in spring 2007, the unusual atmospheric pattern that followed would not have been nearly as effective at reducing ice extent as was observed.

Subsequent autumn freeze-up began rather late, as time was needed for the Arctic Ocean mixed layer to lose its heat. However, once freeze-up began, it proceeded quickly. Ice extent averaged for March 2008 was 4\% greater than for 2007 and only $3 \%$ below climatology. Nevertheless, $72 \%$ of the ice cover consisted of thin, first-year ice (reflecting the vast expanses of open water in September 2007 and delayed ice formation), compared to $55 \%$ in 2007 . These results, based on the ice-age tracking dataset, are supported by thickness estimates based on data from both the ICESat laser altimeter and European Space Agency (ESA) ERS-1 and ERS-2 radar altimeter (Giles et al. 2008). According to these estimates, the ice cover in spring 2008 was nearly $50 \mathrm{~cm}$ thinner in the western Arctic and $10 \mathrm{~cm}$ thinner in the eastern Arctic compared to 2007. It is largely because of the extensive coverage of this thin ice that there was widespread expectation, supported by projections based on both statistical approaches (Drobot et al. 2008) and simulations with a coupled ice-ocean model (Zhang et al. 2008), that the record low ice extent of September 2007 would be followed by another pronounced minimum in September of 2008. Zhang et al. (2008) further suggest that had the same atmospheric forcings seen in 2007 been repeated for 2008, the September minimum would have ended up slightly lower than for 2007. As it turned out, September 2008 ice extent was the second lowest on record, with a monthly mean of 4.68 million $\mathrm{km}^{2}$ compared to 4.30 million $\mathrm{km}^{2}$ in 2007 (Fig. 1).

Contributors to the 2009 Sea Ice Outlook from the Study of Environmental Arctic Change (SEARCH) projected a median value of 4.7 million $\mathrm{km}^{2}$ for the monthly mean September 2009 minimum based on May data, with a range of 4.2-5.0 million $\mathrm{km}^{2}$. These estimates were largely based on continuation of the large coverage of thin, first-year ice during spring compared to previous decades. Interestingly, these estimates fell far below the observed value of 5.36 million $\mathrm{km}^{2}$. 
The 2010 melt season started out with more multiyear ice than seen in 2008 and 2009, and contributors to the SEARCH June Outlook report projected a range between 4.2 and 5.7 million $\mathrm{km}^{2}$ for the monthly mean September minimum, based in part on the increased multiyear ice coverage. Yet, 2010 saw record ice loss rates in May and June, leading to a new record low for the month of June and a September minimum that was only $40,000 \mathrm{~km}^{2}$ above that observed in September 2008. This happened despite a very negative AO state that characterized winter 2009/2010, leading to transport of old, thick ice into the southern Beaufort and Chukchi seas that should have helped to slow summer ice loss (Stroeve et al. 2011).

Why were no new record minima set in the last 3 years given that for all 3 years there was more thin ice starting out the melt season than for 2007? Averaged over May through August, the atmospheric sea level pressure pattern for the 4 years was broadly similar (Fig. 8). Yet there are some important differences. During 2008, the Beaufort Sea High was weaker, with the highest pressure located over Greenland. In addition, the area of lowest pressure over Siberia was located further south than in 2007. As in 2007, the highest pressure was located over the Canada Basin in 2009 and 2010, but the area of lowest pressure over Siberia was again further south.

The timing and persistence of circulation anomalies was also important. The dipole pattern was well expressed for all summer months of 2007, whereas in 2008, it was strong early in the melt season but weaker during July and August. Similarly, in 2009 the DA persisted through June and July, yet the pattern changed completely in August when low pressure dominated the Beaufort and Chukchi seas, coupled with high pressure over Greenland and the Atlantic side of the Arctic. Cyclonic winds over the Beaufort and Chukchi seas likely favored ice divergence (e.g. Ogi
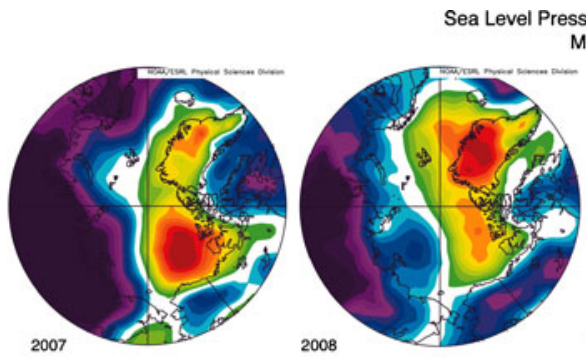
May to August
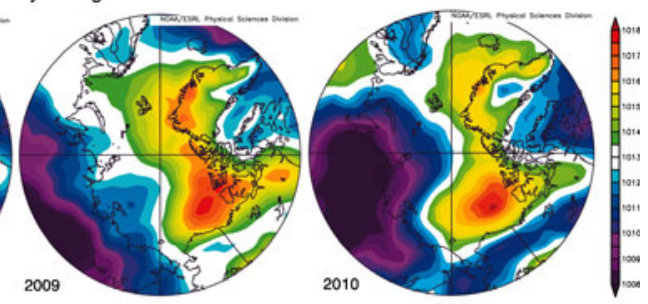

$925 \mathrm{mb}$ Air Temperature Anomaly (degrees C) May-August
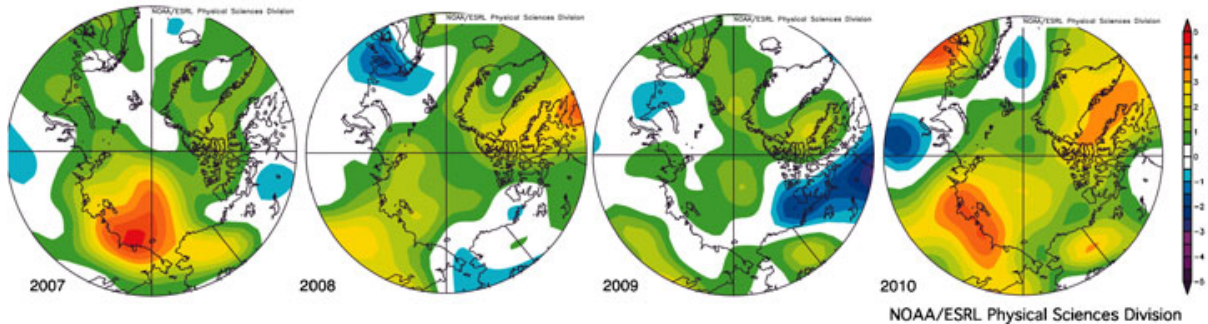

Fig. 8 May through August mean sea level pressure (SLP) [top] and $925 \mathrm{hPa}$ air temperature anomalies [bottom] for 2007 through 2010 based on data from the JRA-25 reanalysis. Anomalies are with respect to the period 1979-2010 
and Wallace 2007), helping to slow the seasonal decline in ice extent through August and September. The DA was present again in May and June of 2010, but disappeared in July when many low pressure systems entered the central Arctic from the Eurasian coast. This caused the ice loss to slow substantially in July 2010, and was an important factor in causing the ice extent to remain above that in 2007 during the rest of the melt season.

The differences in sea level pressure distributions in 2008, 2009 and 2010 not only resulted in weaker southerly winds in the East Siberian Sea sector compared to 2007, but, as evident in the bottom panels of Fig. 8, there were smaller positive air temperature anomalies than in 2007. Cloud patterns during the 2008, 2009 and 2010 melt seasons also favored retention of ice (e.g. Kay et al. 2008). Compared to summer 2007, which had relatively clear skies associated with the strong Beaufort High, especially pronounced near the solstice, cloud cover in summers 2008, 2009 and 2010 was overall more extensive (Fig. 9).

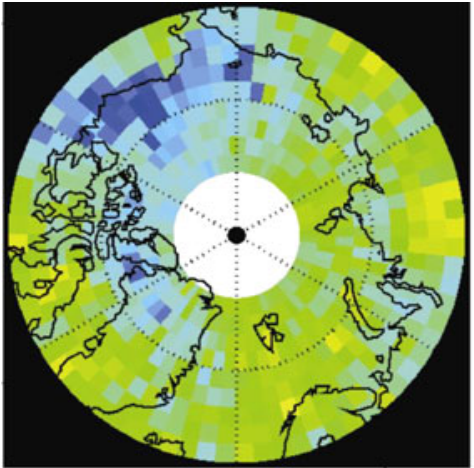

2007

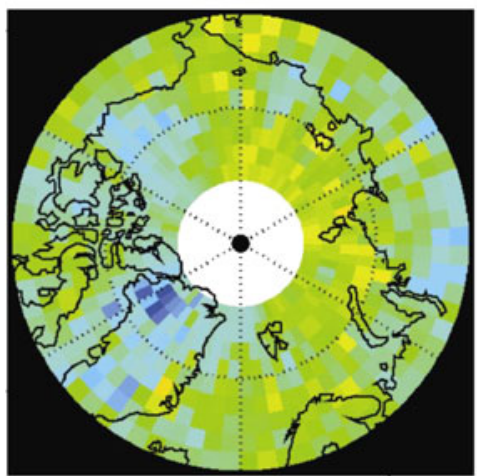

2009

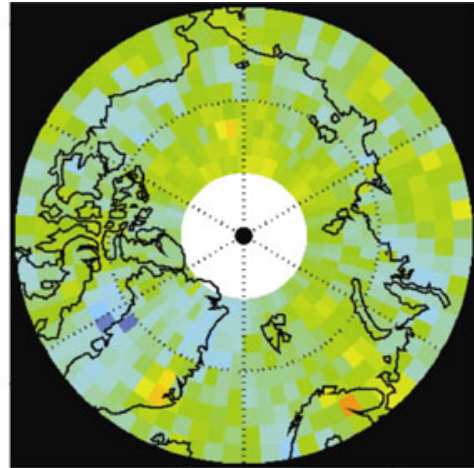

2008

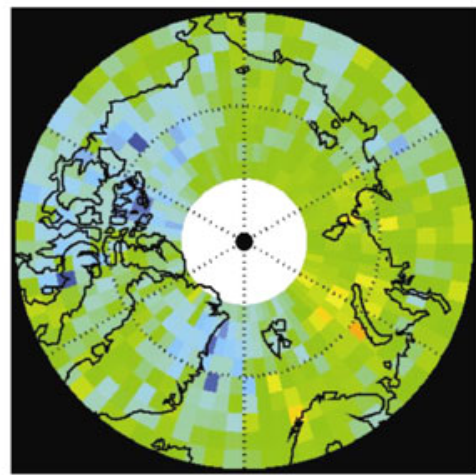

2010

\section{CloudSat Total Cloud Fraction June 1 - September 1 \\ 0.5}

Fig. 9 Total cloud cover for summer 2007 through 2010 derived from CloudSat data. Atmospheric columns are defined as cloudy if the total cloud thickness detected exceeds $960 \mathrm{~m}$ 
While failing to set a new record minimum, 2008 nevertheless saw the largest decline of ice extent over a single melt season (defined as the difference in ice extent between the maximum and minimum ice extent from that year) recorded in the satellite era of 10.67 million $\mathrm{km}^{2}$. The reason 2008 had a greater total seasonal ice loss than in 2007 (10.56 million $\left.\mathrm{km}^{2}\right)$ is that the melt season started out with greater ice extent than 2007. Had there been less ice at the beginning of the melt season, 2008 may have broken the record seasonal minimum of September 2007, despite less favorable atmospheric forcings, simply because so much of the spring ice pack consisted of first-year ice, more so than at any other time during the satellite data record. In 2009, the total ice loss between March and September was 10.04 million $\mathrm{km}^{2}$, and in 2010 it was 10.49 million $\mathrm{km}^{2}$, fourth and third largest. At no other time during the satellite data record was there a total ice loss from maximum to minimum that exceeded 10 million $\mathrm{km}^{2}$.

Regional patterns of summer ice loss are enlightening in this regard. Figure 10 shows daily average changes in ice extent for six regions for June through August of the 4 years. June 2007 saw stronger than average daily ice retreat in all sectors except the Kara Sea, with especially strong retreat in the Chukchi and East Siberian seas. June ice losses were comparatively slower in 2008 in all sectors except the Beaufort Sea, where the daily loss rate was $7,230 \mathrm{~km}^{2}$ day $^{-1}$, exceeding that observed in 2007 by $5,330 \mathrm{~km}^{2} \mathrm{day}^{-1}$. Ice loss began early in the Beaufort in 2008 when large polynyas formed off the coast in Alaska during May. As mentioned, thickness estimates from ERS-1 and ERS-2 data suggest that ice in the western Arctic was about $50 \mathrm{~cm}$ thinner in spring 2008 than in 2007 (Giles et al. 2008) and estimates for the Beaufort Sea suggest a mean thickness anomaly of $-36 \mathrm{~cm}$ compared to 2007. The earlier development of open water areas in this region is consistent with a younger (thinner) spring ice cover, helping to enhance the summer ice-albedo feedback discussed earlier. Ice loss in June 2009 was also higher than climatology in all regions except the Kara Sea, with particularly high rates of loss in the Laptev Sea $\left(5,160 \mathrm{~km}^{2} \mathrm{day}^{-1}\right)$, reflecting a combination of thin ice and warm temperatures and southerly winds throughout June. The rapid pace of ice loss observed during June 2010 that helped to bring a new record low for the month was dominated by record ice loss in the Kara Sea, as well as rapid ice loss in the Beaufort and Chukchi seas.

The obvious feature for July is above-average daily retreats in all sectors for the last 4 years. In the Beaufort Sea, ice loss continued to be faster in 2008 than in 2007. By contrast, July 2007 ice losses greatly exceeded those for 2008, 2009 and 2010 in the East Siberian and Laptev seas. Interestingly, ice loss for the Arctic as a whole in July 2009 rivaled that observed in $2007\left(106,000 \mathrm{~km}^{2}\right.$ day $^{-1}$ in 2009 compared to $107,000 \mathrm{~km}^{2}$ day $^{-1}$ in 2007), driven in large part by rapid ice loss in the Kara Sea. By contrast, ice loss rates in July 2010 were slower than climatology, dropping to $77,000 \mathrm{~km}^{2} \mathrm{day}^{-1}$. These regional contrasts reflect in part the differences in the strength and persistence of the DA atmospheric pattern between the 4 years. In early July 2007 the DA pattern was particularly strong, which led to warm southerly winds in the East Siberian and Laptev Sea sectors and anomalously clear skies over the Beaufort Sea. This is reflected in the sharp drop in July 2007 ice extent for the Arctic as a whole. The weaker dipole pattern in July 2008 and 2009 led to slower ice loss in the East Siberian and Laptev seas compared to 2007, but stronger ice loss in other regions. The replacement of the DA by low pressure in the central Arctic significantly 
Fig. 10 Monthly averaged daily ice loss rates for six regions (see inset) from June through August for 2007 through 2010 and for the 1979-2000 average. The subregions are those defined by Meier et al. (2007) using a modified version of the Arctic regional mask developed by Parkinson et al. (1999)

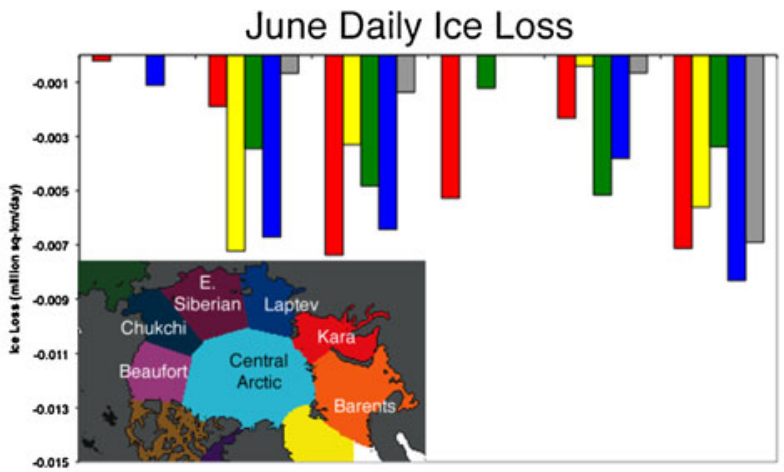

July Daily Ice Loss

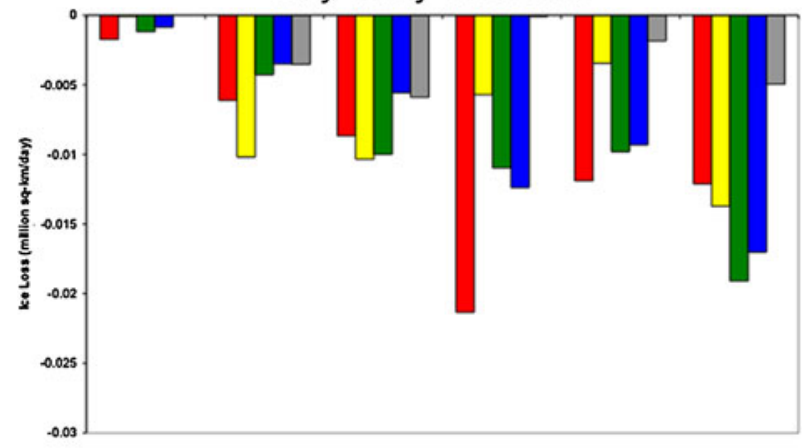

August Daily Ice Loss

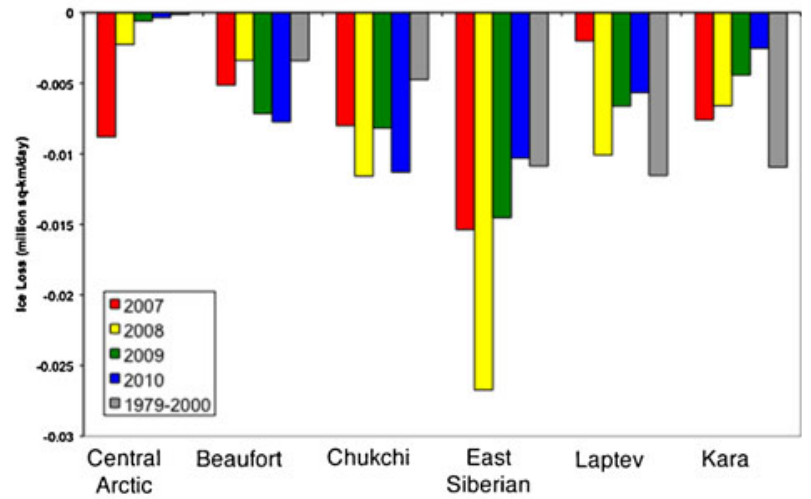

Region

slowed ice loss in the western Arctic in July 2010, while ice loss in the eastern Arctic continued at a fast pace.

While August ice loss rates for 2007 and 2008 were comparable for most regions (though still faster than climatology), ice loss in August 2008 was very rapid in the East Siberian Sea. Daily average ice loss in this region was over twice climatology $\left(15,830 \mathrm{~km}^{2} \mathrm{day}^{-1}\right.$ faster $)$ and $11,340 \mathrm{~km}^{2} \mathrm{day}^{-1}$ faster than in 2007 . It was the large 
August losses in this sector that led to a record August ice loss for the Arctic as a whole in 2008. Usually, the rate of daily ice loss for the Arctic slows in August in response to declining insolation; this pattern was observed even in 2007. In 2008, however, the daily loss rate stayed fairly steady throughout the month. The record ice loss in August 2008 is evidence of the importance of thin spring ice in defining the end of summer ice extent, as the ice cover simply began to run out of thickness. Smaller rates of decline in most sectors during August 2009 manifest development of a low pressure region over the Laptev Sea, which combined with a high over the Barents Sea fostered a wind pattern helping to transport ice toward the Siberian coast and discouraging ice export out of the Arctic Ocean. However, while ice divergence increases extent, it can also accelerate melt by exposing more dark open water areas between the ice floes. Continued rapid rates of ice loss in the Beaufort and Chukchi seas in August 2009 may reflect this process. As sea ice largely disappeared in the Kara and Laptev seas by the end of August 2010, the ice loss rates slowed significantly, whereas they picked up again in the western Arctic (e.g. Beaufort and Chukchi seas) as the DA pattern once again redeveloped.

\subsection{Predictability}

What do the results in this paper imply in terms of predictability of future sea ice conditions? Consider two sea ice regimes, one in a cool pre-industrial age and another in a warmer climate regime. Compared to the cool regime, the spring ice cover in the warm regime will consist of less old, thick ice and more thin, first-year ice, as well as a lower winter ice extent. It follows that there will be less ice in the warm regime in September - the thin ice melts out easily, the summer ice-albedo feedback is stronger, and it is simply warmer. We can broadly view what is being observed in the real world since about 2002 in the context of a warmer regime. Compared to 30 years ago, when the ice was still in the cooler regime, today there is more thin ice in spring, enhanced shortwave radiation absorption and a warmer climate. We can predict with confidence that there will be less ice in September than there used to be (September ice extent averaged for 2007-2010 is typically $40 \%$ less than it was 20 to 30 years ago). The analogy is of course far from perfect, for, as is evident in the steeper downward trend in September ice extent over the past decade (Figs. 1 and 3) and anomalous summer ice losses for the last 4 years (Fig. 10), the sea ice system is far from an equilibrium state.

The view of comparing conditions in two regimes should not be confused with the issue of predictability of ice extent from one September to another in a given regime.

A priori, one might expect a significant lag-one autocorrelation in September ice extent, such that a September with an unusually low (high) extent would tend to be followed by another September with low (high) extent. This follows in that while the amount of open water at the end of the melt season helps to determine the fractional area of first-year ice the next spring, this ice would be especially prone to melting out the following summer, leading to low ice extent in September.

We can approximate the autocorrelation in an equilibrium regime by analyzing the observed de-trended time series (with the caveat that the effect of recent steepening of the trend will still be there). As evaluated using the entire satellite record (19792010), the 1-year autocorrelation in September ice extent is close to zero (0.06). In other words, there is actually little inherent "memory" from one September to 
another, a result also found by Bitz (2008). While we have shown that September ice extent is reflected in the following spring coverage of first-year ice, this "halfyear" memory seems to be erased due to variability in atmospheric and oceanic conditions during summer. Going back to the two regime model, we see no physical reason why there should be a stronger autocorrelation in the warm versus the cold system.

That said, many studies use spring ice conditions in their seasonal forecasts (e.g. Drobot et al. 2006; Lindsay et al. 2008). As assessed over the available record, spring first-year ice fraction and the subsequent September total ice extent is fairly strongly correlated $(R=-0.68)$. This correlation, however, is primarily driven by the strong linear trends in both time series. De-trended data show no correlation $(R=-0.03)$. Climate model simulations nevertheless suggest that the relationship between detrended March ice thickness and the end of summer ice extent will strengthen as the thickness of the ice decreases. Figure 11 shows the correlation between detrended 20-year segments of March Arctic average ice thickness and the following September ice area from 1950 to 2050 using linear least square regression, based on eight ensemble members from the NCAR Community Climate System Model Version 3 (CCSM3). The September ice extent is correlated with the prior March ice thickness at only 0.2 in the mid twentieth century (when the ensemble mean ice thickness is $3.6 \mathrm{~m}$ ) but the correlation increases to 0.6 as the spring ice cover thins through 2050 (the ensemble mean ice thickness has decreased to $1.4 \mathrm{~m}$ by 2050). By comparison, the mean Arctic Ocean ice thickness was estimated to be $2.4 \mathrm{~m}$ in spring 2008 (Kwok et al. 2009). Thus, according to CCSM3 model simulations, spring ice thickness anomalies may eventually provide some predictive skill for the end-ofsummer ice cover as the Arctic transitions to increasingly thinner sea ice.

Might the Arctic sea ice cover be approaching a critical threshold at which there is a rapid transition to a seasonally ice-free state? Schefer et al. (2009) argue that before a system is close to a critical threshold, there is a 'critical slowing down', i.e., the system becomes increasingly slow in recovering from perturbations which leads to an increase in the 'memory' of the system. In the context of the Arctic sea ice cover, this implies that a September with low (high) sea ice extent will be followed by low (high) extent the next September. An increase in lag-1 autocorrelation can be interpreted as slowness of recovery. While there is no evidence in the available sea

Fig. 11 Correlation between de-trended 20-year segments of March Arctic average ice thickness and the following September ice extent from 1950 to 2050 . Results are based on eight ensemble members from the NCAR Community Climate System Model Version 3 (CCSM3) using observed climate forcings through the twentieth century and the A1B emissions scenario thereafter

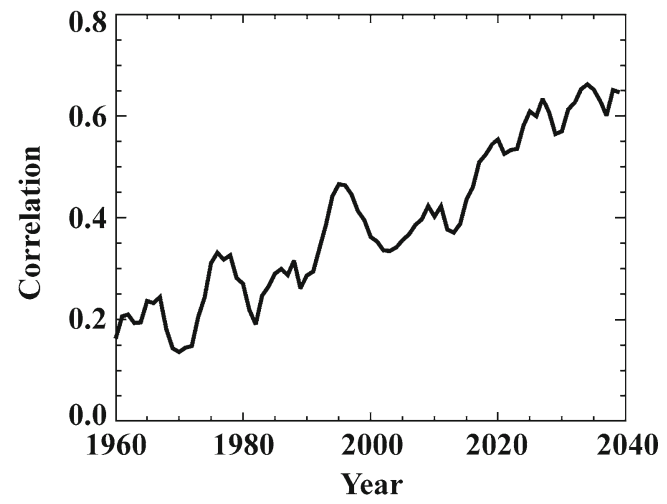


ice record of a significant lag-1 autocorrelation, as just discussed there is modeling evidence that the autocorrelation will rise as the ice cover continues to thin.

\section{Discussion and conclusions}

As illustrated schematically in Fig. 2, the recent steepening of the downward September trend in Arctic sea ice extent involves a suite of linked processes. Arctic air temperatures are rising in all seasons. This is linked to more open water in September and in turn, a thinner ice cover in spring. Earlier development of open water in the melt season enhances the summer ice-albedo feedback, promoting even more open water in September. Strong autumn warming over ice-free ocean areas influences the adjacent ice cover, contributing to further thinning. With more thin ice starting the melt season compared to 20 years ago, atmospheric patterns favoring summer ice loss, such as seen in summer 2007, are more effective than they used to be. Conversely, atmospheric patterns that favor ice retention are becoming less effective (e.g. Stroeve et al. 2011). Finally, as the Arctic continues to warm in response to radiative forcing, the probability of a sequence of unusually cold years in the Arctic that could bring about recovery declines.

A potential major player in the observed sea ice retreat that remains to be fully understood is ocean forcing. Warm Atlantic waters enter the Arctic Ocean through eastern Fram Strait and the Barents Sea, and form an intermediate layer as they subduct below colder, fresher (less dense) Arctic surface waters. While this inflow is quite variable, it appears that 1990s onwards has seen an overall increase in the temperature and transport of Atlantic water through Fram Strait (Schauer et al. 2004; Polyakov et al. 2005; Dimitrenko et al. 2008). While this increase in Atlantic layer heat has the potential to promote summer melt and reduce winter growth, it is as yet unclear as to how much of this heat can be brought to the surface to influence the ice cover.

Other studies find links with Pacific water inflow. Shimada et al. (2006) note a concurrence between increases in Pacific Surface Water (PSW) temperature in the Arctic Ocean beginning in the late 1990s and the onset of sharp summer sea ice reductions in the Chukchi and Beaufort seas. They hypothesize that delayed winter ice formation allows for more efficient coupling between the ocean and wind forcing. This redirects warm PSW from the shelf slope along Alaska into the Arctic Ocean, where it is more efficient in retarding winter ice growth. An imbalance between winter ice growth and summer melt results, accelerating ice loss over a large area.

Jackson et al. (2010) focus on changes in the near surface (20-25 m depth) temperature maximum (NSTM) in the Canada Basin. This temperature maximum forms from mid-June to mid-July when there is enough solar radiation entering the upper ocean though leads and polynyas to warm the near surface waters. Through sea ice melt, a near-surface halocline forms below the mixed layer from June through mid August, acting as a cap which stores the heat gained in summer. Based on data from 1993 through 2007, the NSTM appears to have warmed and expanded northward. Both the NSTM and halocline are found at shallower depths, and the stronger near surface stratification from increasing ice melt stores the heat in the NSTM for longer periods of time. This stored can then be used to melt ice and reduce ice thickness. 
After the 2007 record September sea ice minimum, there was widespread speculation that the Arctic Ocean was rapidly transitioning towards seasonally icefree conditions. With these processes described above working together to support further ice loss, combined with the greater ease at which anomalous atmospheric forcing can cause dramatic summer ice loss, the system may be poised to undergo rapid change.

However, given the shortness of the available sea ice extent time series, the apparent steepening of the downward September trend may not be sustained. Climate model simulations reveal periods of rapid ice loss are often followed by a temporary recovery. Given natural variability in the coupled ice-ocean-atmosphere system, a few years of sea ice recovery, such as evident between 2007 and 2009, should come as no surprise.

Acknowledgements This study was supported by NASA grants NNG04GO51G and NNG06GB26G and NSF grants ARC-0531040 and ARC-0531302 and ARC-0901962. The reanalysis datasets used for this study are from the JRA-25 long-term reanalysis cooperative research project carried out by the Japan Meteorological Agency (JMA) and the Central Research Institute of Electric Power Industry (CRIEPI). The sea ice data are available from the National Snow and Ice Data Center (NSIDC).

Open Access This article is distributed under the terms of the Creative Commons Attribution Noncommercial License which permits any noncommercial use, distribution, and reproduction in any medium, provided the original author(s) and source are credited.

\section{References}

Arctic Climate Impact Assessment (ACIA) (2004) Impacts of a warming arctic. Cambridge University Press, Cambridge, UK, p 139

Belchansky GI, Douglas DC, Platonov NG (2004) Duration of the Arctic sea ice melt season: regional and interannual variability, 1979-2001. J Clim 17, 67-80

Bitz CM (2008) Some aspects of uncertainty in predicting sea ice retreat, in Arctic Sea Ice Decline: observations, projections, mechanisms, and implications. In: deWeaver E, Bitz CM, Tremblay B (eds) AGU geophysical monograph series. American Geophysical Union, pp 63-76

Cavalieri D, Parkinson C, Gloersen P, Zwally HJ (1996) Sea ice concentrations from Nimbus7 SMMR and DMSP SSM/I passive microwave data, 1978-2007. Boulder, Colorado USA: National Snow and Ice Data Center. Digital media (updated 2008)

Cleveland WS, Devlin SJ (1988) Locally weighted regression: an approach to regression analysis by local fitting. J Am Stat Assoc 83(403):596-610. doi:10.2307/2289282

Comiso JC, Parkinson CL, Gersten R, Stock L (2008) Accelerated decline in the Arctic sea ice cover. Geophys Res Lett 35:L01703. doi:10.1029/2007GL031972

Dimitrenko IA, Polyakov IV, Krillov SA, Timokhov LA, Frolov IE, Sokolov VT, Simmons HL, Ivnov VV, Walsh D (2008) Toward a warmer Arctic Ocean: spreading the early 21st century Atlantic Water warm anomaly along the Eurasian Basin margins. J Geophys Res 113:C05023. doi:10.1029/2007JC004158

Drobot SD, Maslanik JA, Fowler C (2006) A long-range forecast of Arctic summer sea ice minimum extent. Geophys Res Lett 33. doi:10.1029/2006GL026216

Drobot S, Stroeve J, Maslanik J, Emery W, Fowler C, Kay J (2008) Evolution of the 2007-2008 Arctic sea ice cover and prospects for a new record in 2008. Geophys Res Lett 35:L19501. doi:10.1029/2008GL035316

Fowler C, Emery WJ, Maslanik J (2004) Satellite-derived evolution of Arctic sea ice age: October 1978 to March 2003. IEEE Geosci Remote Sens Soc Lett 1(2):71-74

Francis JA, Hunter E (2006) New insight into the disappearing Arctic sea ice. Eos Trans AGU 87:509-511

Giles KA, Laxon SW, Ridout AL (2008) Circumpolar thinning of Arctic sea ice following the 2007 record ice extent minimum. Geophys Res Lett 35:L22502. doi:10.1029/2008GL035710 
Holland MM, Bitz CM, Tremblay B (2006) Future abrupt reductions in the summer Arctic sea ice. Geophys Res Lett 33:L23503. doi:10.1029/2006GL028024

Holland MM, Bitz CM, Tremblay B, Bailey DA (2008) The role of natural versus forced change in future rapid summer Arctic ice loss. In: DeWeaver ET, Bitz CM, Tremblay L-B (eds) Arctic sea ice decline: observations, projections, mechanisms, and implications. Geophys Monogr Ser, 180. AGU, Washington, D.C., pp 133-150

Jackson JM, Carmack EC, Mc Laughlin FA, Allen SE, Ingram RG (2010) Identification, characterization, and change of the near-surface temperature maximum in the Canada Basin, 1993-2008. J Geophys Res 115:C05021. doi:10.1029/2009JC005265

Kay JE, L'Ecuyer T, Gettelman A, Stephens G, O'Dell C (2008) The contribution of cloud and radiation anomalies to the 2007 Arctic sea ice extent minimum. Geophys Res Lett 35:L08503. doi:10.1029/2008GL033451

Kwok R, Cunningham GF, Wensnahan M, Rigor I, Zwally HJ (2009) Thinning and volume loss of the Arctic Ocean sea ice cover: 2003-2008. J Geophys Res Oceans 114(C07005). doi:10.1029/2009JC005312

L'Heureux ML, Kumar A, Bell GD, Halpert MS, Higgins RW (2008) Role of the Pacific-North American (PNA) pattern in the 2007 Arctic sea ice decline. Geophys Res Lett 35:L20701. doi:10.1029/2008GL035205

Lindsay RW, Zhang J (2005) The thinning of Arctic sea ice, 1988-2003: have we passed a tipping point? J Climate 18:4879-4894

Lindsay RW, Zhang J, Schweiger AJ, Steele MA (2008) Seasonal predictions of ice extent in the Arctic Ocean. J Geophys Res 113:C02023. doi:10.1029/2007JC004259

Lindsay RW, Zhang J, Schweiger A, Steele M, Stern H (2009) Arctic sea ice retreat in 2007 follows thinning trend. J Climate. doi:10.1175/2008JCLI2521.1

Markus T, Stroeve JC, Miller J (2009) Recent changes in Arctic sea ice melt onset, freezeup, and melt season length. J Geophys Res 114:C12024. doi:10.1029/2009JC005436

Maslanik JA, Fowler C, Stroeve J, Drobot S, Zwally HJ, Yi D, Emery WJ (2007) A younger, thinner ice cover: increased potential for rapid, extensive ice loss. Geophys Res Lett 34:L24501. doi:10.1029/2007GL032043

Meier W, Fetterer F, Knowles K, Savoie M, Brodzik MJ (2006) Sea ice concentrations from Nimbus7 SMMR and DMSP SSM/I passive microwave data, 2008. Boulder, Colorado USA: National Snow and Ice Data Center. Digital media (updated 2008)

Meier WN, Stroeve J, Fetterer F (2007) Whither Arctic sea ice?: a clear signal of decline regionally, seasonally, and extending beyond the satellite record. Ann Glaciol 46:428-434

Nghiem SV, Rigor IG, Perovich DK, Clemente-Colón P, Richter-Menge J, Weatherly JW, Neumann G (2007) Rapid reduction of Arctic perennial sea ice. Geophys Res Lett 24:L19504. doi:10.1029/2007GL031128

Ogi M, Wallace JM (2007) Summer minimum Arctic sea ice extent and the associated summer atmospheric circulation. Geophys Res Lett 34. doi:10.1029/2007GL029897

Ogi M, Rigor IG, McPhee MG, Wallace JM (2008) Summer retreat of Arctic sea ice: role of summer winds. Geophys Res Lett 35:L24701. doi:10.1029/2008GL035672

Onogi K, Tsutsui J, Koide H, Sakamoto M, Kobayashi S, Hatsushika H, Matsumoto T, Yamazaki S, Kamahori H, Takahashi K, Kadokura S, Wada K, Kato K, Oyama R, Ose T, Mannoji N, Taira R (2007) The JRA-25 reanalysis. J Meteorol Soc Jpn 85:369-432

Overland JE, Wang M, Salo S (2008) The recent Arctic warm period. Tellus 60A:589-597

Parkinson CL, Cavalieri DJ, Gloersen P, Zwally HJ, Comiso JC (1999) Arctic sea ice extents, areas and trends, 1978-1996. J Geophys Res 104(C9):20,837-20,856

Perovich DK, Light B, Eicken H, Jones KF, Runciman K, Nghiem SV (2007) Increasing solar heating of the Arctic Ocean and adjacent seas, 1979-2005: attribution and role in the ice-albedo feedback. Geophys Res Lett 34:L19505. doi:10.1029/2007GL031480

Perovich DK, Richter-Menge JA, Jones KF, Light B (2008) Sunlight, water and ice: extreme Arctic sea ice melt during the summer of 2007. Geophys Res Lett 35:L11501. doi:10.1029/2008GL034007

Polyakov IV, et al (2005) One more step toward a warmer Arctic. Geophys Res Lett 32:L17605. doi:10.1029/2005GL023740

Rigor IG, Wallace JM (2004) Variations in the age of Arctic sea-ice and summer sea-ice extent. Geophys Res Lett 31:L09401. doi:10.1029/2004GL019492

Rigor IG, Wallace JM, Colony RL (2002) Response of sea-ice to the Arctic Oscillation. J Clim $15: 2648-2663$ 
Schauer U, Fahrbach E, Osterhus S, Rohardt G (2004) Arctic warming through the Fram Strait-Oceanic heat transport from three years of measurements. J Geophys Res 109:C06026. doi:10.1029/203JC001823

Schefer M, Bascompte J, Brock WA, Brovkin V, Carpenter SR, Dakos V, Held H, van Nes EH, Rietkerk M, Sugihara G (2009) Early-warning signals for critical transitions. Nature 461. doi:10.1038/nature08227

Schweiger AJ, Zhang J, Lindsay RW, Steele M (2008) Did unusually sunny skies help drive the record sea ice minimum of 2007? Geophys Res Lett 35:L10503. doi:10.1029/2008GL033463

Screen JA, Simmonds I (2010) The central role of diminishing sea ice in recent Arctic temperature amplification. Nature 464. doi:10.1038/nature09051

Serreze MC, Holland MM, Stroeve J (2007a) Perspectives on the Arctic's shrinking sea ice cover. Science 315:1533-1536

Serreze MC, Barrett AP, Slater AJ, Steele M, Zhang J, Trenberth KE (2007b) The large-scale energy budget of the Arctic. J Geophys Res 112:D11122. doi:10.1029/2006JD008230

Serreze MC, Barrett AP, Stroeve JC, Kindig DM, Holland MM (2009) The emergence of surfacebased Arctic amplification. Cryosphere 3:11-19

Shindell D, Faluvegi G (2009) Climate response to regional radiative forcing during the twentieth century. Nature Geoscience 2:294-300. doi:10.1038/NGE0473

Shimada K, Kamoshida T, Itoh M, Nishino S, Carmack E, McLaughlin F, Zimmerman S, Proshutinsky A (2006) Pacific Ocean inflow: influence on catastrophic reduction of sea ice cover in the Arctic Ocean. Geophys Res Lett 33:L08605. doi:10.1029/2005GL025624

Steffen K, Cavalieri DJ, Comiso JC, St. Germain K, Gloersen P, Key J, Rubinstein I (1992) The estimation of geophysical parameters using passive microwave algorithms. Chapt 10. In: Carsey F (ed) Microwave remote sensing of sea ice. Washington, D.C., American Geophysical Union, pp 243-259

Stephens GL et al (2008) CloudSat mission: performance and early science after the first year of operation. J Geophys Res 113:D00A18. doi:10.1029/2008JD009982

Stroeve J, Holland MM, Meier W, Scambos T, Serreze M (2007) Arctic sea ice decline: faster than forecast. Geophys Res Lett 34. doi:10.1029/2007GL029703

Stroeve J, Serreze M, Drobot S, Gearheard S, Holland M, Maslanik J, Meier W, Scambos T (2008) Arctic sea ice extent plummets in 2007. EOS Trans, AGU 89(2):13-14

Stroeve JC, Maslanik J, Serreze MC, Rigor I, Meier W (2011) Sea ice response to an extreme negative phase of the Arctic Oscillation during winter 2009/2010. Geophys Res Lett. doi:10.1029/2010GL045662

Walsh JE, Chapman WL, Portis DH (2009) Arctic cloud fraction and radiative fluxes in atmospheric reanalysis. J Clim 22:2316-2334

Wang M, Overland JE (2009) A sea ice free summer Arctic within 30 years? Geophys Res Lett 36:L07502. doi:10.1029/2009GL037820

Wang J, Zhang J, Watanabe E, Ikeda M, Mizobata K, Walsh JE, Bai X, Wu B (2009) Is the dipole anomaly a major drier to record lows in Arctic summer sea ice extent? Geophys Res Lett 36:L05706. doi:10.1029/2008GL036706

Wu B, Wang J, Walsh JE (2006) Dipole anomaly in the winter Arctic atmosphere and its association with sea ice motion. J Clim 19:210-225

Yang X-Y, Fyfe JC, Flato GM (2010) The role of poleward energy transport in Arctic temperature evolution. Geophys Res Lett 37:L14803. doi:10.1029/2010GL042487

Zhang X, Walsh JE (2006) Toward a seasonally ice-covered Arctic Ocean: scenarios from the IPCC AR4 model simulations. J Clim 19:1730-1747

Zhang J, Steele M, Lindsay R, Schweiger A, Morison J (2008) Ensemble 1-Year predictions of Arctic sea ice for the spring and summer of 2008. Geophys Res Lett 35:L08502. doi:10.1029/2008GL033244 